\title{
Maintaining Student's Tolerance Character through Religious Education: A case study at the 2nd Senior High School in Palangka Raya City
}

\author{
Hayadin $^{1}$, Qowaid ${ }^{2}$, Farida Hanun ${ }^{3}$, Lisadiyah Marifataini ${ }^{4}$, Achmad Habibullah $^{5}$, Suprapto ${ }^{6}$, \\ Siti Muhibah ${ }^{7}$, Suhardin $^{8,}$ Supriyadi ${ }^{9}$ \\ \{hayadin006@gmail.com¹, qowaidbmasyhuri@gmail.com², farida_ridwan@yahoo.com³ \\ lisa.litbang@gmail.com ${ }^{4}$, achmadhabibullah@yahoo.com ${ }^{5}$, supraptolitbang@gmail.com 6 , \\ sitimuhibbah@gmail.com ${ }^{7}$, suhardin@yahoo.com ${ }^{8}$, supriyadiesbe@gmail.com ${ }^{9}$ \} \\ The Center of Religious Education R\&D Ministry of Religious Affairs, Jakarta 1,2,3,4,5,6 \\ University of Sultan Ageng Tirtayasa, Serang, Banten, Indonesia ${ }^{7}$ \\ University of Ibnu Chaldun, Jakarta ${ }^{8}$ \\ STKIP of Pancasakti, Jakarta ${ }^{9}$
}

\begin{abstract}
This study aims to describe the implementation of religious education in schools in order to maintain a tolerant character among religious students. The study was conducted in 2014 with a qualitative method in The 2nd Senior High School of Palangka Raya. Data collected used observation, interviews, focus group discussion, and documents. Research respondents consisted of school leaders, Islamic, Christian, Catholic, and Hindu religious teachers; students, and school committees. The results showed that The 2nd Senior High School of Palangka Raya in which was one of the pioneers of character education was proven to be able to foster tolerance among religious students. The efforts in maintaining tolerance were carried out through various approach, one of which was through religious education with intra-curricular ways, extracurricular ways, and through habituation ways.
\end{abstract}

Keywords: Religious education, tolerant character, intra-curricular, extracurricular, habituation

\section{Introduction}

Religious education and (in)tolerance in schools became the actual and important issues nowadays. Many countries had taken part in solving that problem [1]. Many researchers guess/ asked of the relationship between religious education and intolerance [2]. Any researcher embedded citizenship education to maintain tolerance, especially in religious schools [3]. Similar to that statement, [4] also argue if religious teaching at school should be part of the compulsory curriculum in order to build mutual understanding among religion and cultures.

Building and maintaining tolerance became important as many schools had minority religious group affiliation. Frequently, there became subject to be discriminate [5]. The minority group often perceived as a strange, foreigner, or even alien [6].

In Indonesia, tolerance is part of character values that must be thought in school. Character education itself has been embedded in the national curriculum since 2010 as part of national character-building policy, customized by the government. The function of religious education in Indonesia was to maintain peaceful coexistence [7]. 
Character education in Indonesia could be seen as the imperative statement of education law number 20 the year 2003. There were stated that the national education functions were to develop competencies, to build nation characters and civilization, and the goals were to develop children potential to become a religious people, having good characters, healthy, diligent, smart, creative, self-reliant, and to become responsible and democratic civils. Since that time, character education becomes a mainstream of national policy. One of the important characters that must be internalized into a student is tolerance.

As Indonesia consist of multiple various tribe, religion, beliefs, and culture, there were many differences among people in Indonesia. That differences potentially could be the root of social problems, unless well managed and treated. In everyday life, Indonesia people should encounter with other different various people from other religion, in which religious education is one of the important things to make them a life in diversity with harmony [8].

Indonesia educational system adopted religious education in schools. It is distinct to the secular system school that separates religion in the curriculum. Even the secular education system was introduced as the strategy to break down intolerance within the schools [9]

Recently, there was opinion in the social sphere that stated if religious education in schools is not important. They stated that religious education thought at schools could create intolerance behavior and attitude among student with various religions. Instead, they proposed value education as the substitute for religious education [10]. Religious education could be the instrument for developing character in general and mainly tolerance character [11].

This research was about tolerance character in school, with the problem question 'was tolerance character could be upbringing at school thorough religious education; and how could religious education build tolerance character to student. The goal of the research was to find out the practice of developing and maintaining tolerance character in schools and how the religious education subject role, through teaching and learning process and whole instructional process, gave a contribution.

\section{Conceptual frameworks}

In a simple meaning, tolerance is respect for diversity. Tolerance may promote peaceful coexistence between diverse groups and favor individual self-actualization. Conversely, intolerance hinders the manifestation of proclivities and talents and demands a heavy toll on those who dare to be different [12]. Richard Florida, as quoted by Berggren, defining tolerance as "openness, inclusiveness, and diversity to all ethnicities, races, and walks of life [13].

[14] stated that tolerance, as we well know, is neither built into our behavior, in the way that physiological needs like hunger and thirst are, nor a universal value practiced by everyone. Tolerance is incompatible with totalitarian regimes, which advocate a single belief system. The object of tolerance, the thing to be tolerated, can be an action or "conduct," a lifestyle or behaviors or a "set of conducts," or a set of beliefs or a "culture" [15].

Thomas Lickona (1989) provided one definition of character. He stated that Character consists of ... values in action. Character ... has three interrelated parts: moral knowing, moral feeling, and moral behavior. Good character consists of knowing the good, desiring the good, and doing the good habits of the mind, habits of the heart, and habits of action.

The character can be of different types such as moral character, spiritual character, physical character, or materialistic character. in this context, moral character defined as highest ethi9cal standard like as obeying law, honesty, sincerity, and courtesy [16]. Moral character can be 
conceptualized as an individual's disposition to think, feel, and behave in an ethical versus unethical manner, or as the subset of individual differences relevant to morality [17].

Character education is about the acquisition and strengthening of virtues (qualities), values (ideas and concepts), and the capacity to make wise choices for a well-?-rounded life and a thriving society [18].

\section{Method}

This research was a case study of the implementation of tolerance character toward religious education subject at school. The focused study was senior high school at Central Kalimantan, namely The Second (2nd) State Senior High School (SMAN 2) at Palangka Raya city. The data collected using interview, document, and observation. Some respondent could be mentioned, among were: head school and vice head school, religious teacher (consist of Islamic religious teacher, Christian, Catholic, Hinduism, and Buddhism teachers), and some of the students.

Since the prior-existing research about character education was vary and has addressed many practices of implementation of character education at schools, this research focused on the practice of implementation of character education in classroom through religious education subject and by the religious teachers. So, to enrich the information, the content analysis towards religious subject content has been added and described.

\section{$4 \quad$ Research finding}

\subsection{The short brief of research location}

The 2nd Senior High School in Palangka Raya located on Jalan K.S. Tubun, No. 2 Palangka Raya city. It established under the Decree of the Minister of Education and Culture number: C.173 / 1983, 9 November 1983. Some school principals have been carving out their dedication in this school. Among them were: Drs. U.S. Subari, from the year $1984-1987$ as the first Principal; then replaced by Drs. Joko Wahyudi, from year1987 - 1996; continued by Drs. Yuwono, from 1996 - 1999; then continued again by Drs. Itar Kamang Iman, from 1999 - 2009; and now (when this research conducted) was Dra. Badah Sari. In the academic year 2011/2012, SMA Negeri 2 Palangka Raya became one of the high schools that became examples of schools that carry out Nation Character Education in Central Kalimantan province.

\subsection{The process of maintaining tolerance within the school}

One particular way of building and maintaining tolerance character in this school is through religious education. There were three ways of implementing RE in strengthening tolerance in schools, namely: intra-curricular way, extracurricular, dan through customization of school culture. 


\subsubsection{Through intra-curricular approach}

Through this approach, whole kinds of character values include tolerance were embedded in religious education subject topics. It was acted since the planning, implementation, and evaluation phase.

\subsubsection{In the planning phase}

In the national curriculum, it is stated that in the learning planning document, character values are stated on each (whole) subject matter. The teachers have made a learning plan that states explicitly the character values contained in each subject matter discussed.

The religion teacher explores, elaborates, and confirms the subject matter with tolerant character values. For an example of Islamic religion subject, the topic of Aqeedah is directly related to religious character. In its translation, Islamic religious teachers are planned (engineered) so that the material or topic does not merely discuss aspects of the Godhead, but was developed and linked to the values of social life which are indirectly given a load of tolerance character, concern for the nature, environment, and others, as well as the other commendable traits. Likewise, with the learning material of Catholic religious education and Christian religious teachers, on the topic "The Meaning of the Church" which is directly an implementation of a religious character. In the planning of the learning, the religion teachers made a relation of the material meaning of the church with several other characters, namely: religious, responsibility, tolerance, social care, discipline. The same thing was done by Hindu religious education teachers when discussing the topic of divine power, in planning the learning of the material was associated with other character values such as discipline, mutual love and tolerance, and respecting God's creatures.

\subsubsection{In the learning implementation phase}

In learning practice, every day, religious teachers start learning activities with a joint prayer together under their respective religions. This phase takes approximately three minutes or up to five minutes. One student led the prayer reading and followed by another student, along with a religious teacher.

After the prayer reading phase, the learning process continues with apperception and discuss or explain the core material. This stage was the core and substance of learning in which the religion teacher explains the subject matter as formulated in the lesson planning documents or as stated in the syllabus and textbook. The subject matter presented was developed or elaborated as broadly as possible, and what the teacher provides examples and explanations related to the values of the nation's character that are relevant, including tolerant characters.

\subsubsection{In the learning evaluation and closing phase}

Learning activities ended with prayer. The difference of the closing prayer and the opening prayer of lesson was lied in the emphasis on reflection at the end of the lesson. Reflection emphasizes the implementation and actualization of behavioral and skills values. In the final stages of the lesson, the teacher sometimes gives a structured assignment to the student according to the topic presented. The teacher also conducts authentic assessments during the learning process in the classroom. 
The assessment was also carried out through student portfolios. At the end of the study, the religious teacher will conduct a portfolio assessment of students, which includes all topics and contains elements of core spiritual, social, knowledge, and skills. For example, the following portfolio of a student named Dewi (not the real name) stated: Do pray before and after class, be disciplined, be honest, be polite, and care about the environment every day. Presenting the results of understanding the topic of the role of humans as caliphs, worship, asmaul husna, husnuzan, Islamic law, and the history of the prophet to build mecca, with a complete, thorough, honest, independent, act quite effectively and creatively, and quite capable of using methods according to scientific principles "

The pattern of evaluation of religious education was also carried out through the Student Activity Sheet (LKS), kind of a supplement supporting materials. The topics and materials contained in the student worksheet were the same as the subject matter contained in the textbooks on religious education.

\subsubsection{Instruction of tolerance character thorough extracurricular approach}

In addition to intra-curricular learning activities in the classroom, inculcation of tolerance character values was also carried out through extracurricular activities. The Extracurricular activities in the school, consist of three main categories, namely: Academic performance, NonAcademic performance, and Organizational skills and performance. Generally extracurricular activities in The 2nd Senior High School in Palangka Raya consist of: Youth scientific groups, Poetry, Choirs, Archipelago fairy tale, Modeling, Long jump, Javelin throw, English Debates and speeches, Futsal, Martial arts (karate), Basketball, Drama, Musical and poetry recitation, Short story writing, Master of Ceremony, Koran reciting competition, Nasyid, Youth Red Cross, Math Lessons Olympics, Scouts, Flag raisers, Spiritual religious groups, traditional sport such as: Terompongan, Degongan, and Enggrang.

Religious extracurricular activities held at the 2nd Senior High School in Palangkaraya oriented to the development of student's religious insights and skills, and habituation in worship. Through these activities, students deepening their religions, and at the same time had the opportunity to show and knowing other religion practices near them in the same school. These activities of extracurricular made student to know and understand the differences of other religion.

The Christian and Catholic students, the main religious extracurricular activities were worship and practice of worship in mini churches, as well as deepening of the Bible and spiritual activities related to the commemoration of the Christian / Catholic holidays. The activity involved a Christian spiritual group or commonly named as ROHKRIS, and Catholic spiritual group or commonly named as ROHKAT from the intra-school student organization or commonly named as OSIS.

The students who were Hindus, extracurricular activities were related to religious exercises (prayers) and ritual processions, which are centered at the school's Temple. Hindu religious teachers were actively involved in supporting students who use the Temple in school.

The students who are Muslim, then their gathering place was an Islamic spiritual group or commonly named as ROHIS. Some of the activities of the ROHIS are to commemorate Islamic holidays, hold religious and devotion training programs at schools, organize the development of student's talents and interests in the fields of religion, giving speeches, praying imams, and preachers, and publishing a wall magazine of Muslim students' religious activities and thoughts. The center of ROHIS activities was in a mini mosque located within the school. 


\subsubsection{Customization of tolerance character through a school culture}

The planting of tolerance character through school culture approach implemented in various ways. There were slogans, houses of worship, religious holidays, daily worship, and prayer. Some written slogans that were relevant to the values of tolerance character in the 2 nd Senior High School Palangka Raya includes: Unite in diversity, harmonious in diversity, work hard on intelligent learning, we hate radicalism, Peace is nice, and Peace is beautiful.

\subsubsection{Worship facilities in schoolyards}

There were three houses of worship at the 2nd Senior High School Palangka Raya, namely the Musholah for Muslim students, the Church for Christian and Catholic students, and a Temple for Hindu students. The three houses of worship became centers of worship activities for students and teachers at SMADA. In addition to places for worship activities, Students and teachers also used it for learning support purposes. The school mosque, for example, was used by Muslim students for religious learning activities, religious practices, centers for the activities of the Islamic Spiritual Group called Hijas SMADA. Near the mosque, there was a place for ablution and lavatory that look clean.

Likewise, the mosque, the mini church became the center activities of Christian and Catholic spiritual groups, and the Temple became the center activities for Hindu students. In the mini church, SMADA is the center of worship activities for students who are Protestant and Catholic Christians. There also carried out the activity of deepening the Bible and spiritual activities.

\subsubsection{Celebrating religious holidays}

The celebration of religious holidays was always held in school by students in collaboration with teachers.

The Islamic holidays that celebrated in school, among are: Birthday the great prophet Muhammad PBUH, Isra-Mi'raj, the Hijriyah (Islamic Lunar) new year, The holy month of Ramadan, Eid Al-Fitri and Eid al-Adha. The Catholic and Christian holidays that celebrate in school were Easter and Christmas. The Hindu religious holidays celebrated at school were Saraswati and Nyepi. The Buddha religious holidays celebrated at school was Saraswati.

The celebration of religious holidays was carried out by involving students, especially administrators of intra-school student organizations (OSIS), and also involved the administrators of the School Committee. School provides opportunities for OSIS to organize activities and invite the full participation of students. School leaders provide facilities and opportunities for students to learn to lead, organizational skills and instill the character of cooperation and responsibility to their students. Students are taught to participate through contributions, get involved in the activity committee, and attendance participation.

\subsubsection{Daily worship}

The implementation of daily worship for students who are Muslims were performed at the Arrahman mosque within the school. Students usually perform the Dhuhr (Midday) prayer, and Asr (afternoon) prayer in the mosque during school hours. In addition, some carry out the Duha Sunnah prayer. Likewise, the Cristian and Catholic student held prayed at mini-church, and Hindu also Buddha held pray at Temple within the school. 


\subsubsection{Praying together}

Prayer becomes an inseparable part of learning activities in class. Prayer is the beginning of opening and closing learning activities. Prayers recited together by being led by students based on their respective religions and beliefs. Some ritual prayers at school were conducted in the class at the beginning and end of the lesson, some are carried out specifically by the teachers in the teacher council room in the early hours before entering class to begin implementing the lesson, and the end of the teaching and learning process.

There was also a procession of joint prayer that was carried out in the field jointly by students and teachers just before the national examination. Students and teachers who were Muslim, Christian, Catholic, Hindu, and Buddhist carried out prayers alternately. When Muslim students have a turn to lead the recitation of prayers in class, then students of other faiths can say prayers silently based on religion. Likewise, if Christian or Hindu students take the lead in reciting prayers, then Muslim and other religious students read their prayers silently according to their respective religions.

Activities among religious students were generally carried out in the daily learning process. In the national holiday commemoration activities, students who came from various religions took part and involved in the events.

In the activities of celebrating religious holidays that celebrated in the school, the teacher council and the school committee were involved regardless of religion. In the celebration of religious holidays, there was no mixing, but separate, because students who celebrate religious holidays take exceptional service about their own beliefs. As for the celebration of national holidays, all students from various religions have mixed and mingled together.

\subsection{The support and obstacle factors}

\subsubsection{The supporting factors}

Some supporting factor of maintaining tolerance in school were school leadership, staffs, and also local government. The school's leaders, especially the school principal, were very concerned with character education, especially in supporting the maintenance of tolerance. In addition to the principal, the vice principals also support each other and work together to instill a culture of tolerance, mutual respect, cooperation, and responsibility. So did the teachers who teach other subjects. All teachers were involved in realizing school programs with noble character.

The role of the school committee was very large in supporting school activities, including for the implementation of character education. The school committee was committed to fulfilling the financial needs of the school, including student activities, student council, and spiritual activities. Parents of students through the school committee provide excellent support.

Local government support for the 2nd Senior High School Palangka Raya was also outstanding. The local government provided many learning facilities to the school. The local government agencies scheduled the school for educational and student events in the city of Palangka Raya and Central Kalimantan province.

The Outsider took participation through various banners. Religious organizations also always ask for participation from school to be involved, such as for activities hijab fashion contest, and Youth for Christ. 


\subsubsection{The obstacle factors}

There were no real obstacle factors that hinder the implementation of tolerant character education through religious education in school internal environmental. Nevertheless, the status, quality, and quantity of religious teachers can also be a double factor, both supporting and inhibiting. The obstacles that come from religious teachers were related to their personal qualities and capacities. Some elderly teachers tough only to fulfill the number of compulsory lesson hours. They were only a few teachers who try to develop creativity and innovation in developing the character of tolerance through education. Their abilities are still very dependent on training.

There were also religious organizations outside the school that have less tolerant and wisdom. Also, there was any religion organization agency, which did not agree with the status of character education within religious education in schools. They sometimes went to school and offer projects and to cooperate in the field of religious teaching or offer library materials.

\section{Discussion}

The empirical facts of building tolerance character in The 2nd Senior High School Palangka Raya was a complete practice and kind of model of religious education thorough which the aim of religious education consist of knowledge, value and experience, and religious teachers became central in facilitating the pedagogical or instructional process [19]. This finding also similar to what [20] found that family relations and religion teachers were playing a pivotal role in building tolerance for students. They involved in the effort of building and maintaining tolerance character in the whole phase and time. They prepared the religion subject with the supporting content related to tolerance, choose the fit textbooks, designed classroom learning, and school environmental, and more than that, religious education teacher lead and give pattern of how to unite and show harmony with others religion teacher at school, so pupil could internalize the message of tolerance. Religious Education teachers became the role model and exemplary for their student.

The role of exemplary and model in disseminating and maintaining tolerance became important. There had been many schools, and education institution implement the exemplary as a learning approach [21].

As the other expert said that the exemplar approach play the leading role in a learning organization [22]. Other than the exemplary approach, the habituation process also more exciting to be discussed, because it involves the whole aspect and system consist of human and environmental. Habituation approach did work on creating living value [23].

\section{Conclusion}

Based on the description above, the following conclusions can be drawn that developing the character of tolerance, through religious education in schools, is carried out through intracurricular, extracurricular, and the creation of school culture through habituation.

In the intra-curricular approach, the development of tolerance character values was carried out through the preparation of lesson plans and subject matter under the national curriculum. 
The challenge was in the competence of teachers to innovate and create learning materials in the form of stories, or visual media that were more communicative and interesting.

In the co-curricular and extracurricular approach, the development of tolerance character values is carried out through a series of religiously oriented student council activities such as religious holidays, spiritual activities.

The development of the character of tolerance in the 2nd Senior High School Palangka Raya was also done consciously through the creation of religious and tolerant school culture. Schools provide facilities for houses of worship. Therefore, students and teachers have the opportunity to worship in the school environment according to their religion, and at the same time, showed respect and cooperation among other religious adherents. Students dialogue with each other in public spaces such as sports and ceremonies fields even though they have previously just come out of different places of worship.

The leadership and role models of teachers, including religious teachers, were significant in creating and maintaining a tolerant school culture. The religious teachers were at the forefront in providing tolerant character pattern and example. The challenge lies in the willingness, and competence of principals to encourage all available resources to build the culture of tolerance. The fulfillment of religious teachers and worship facilities for all children by their respective religions have a profound effect on fostering mutual respect, and tolerance among different religions.

\section{Recommendations}

In order to strengthen the development of tolerance through religious education, this study recommends that schools need to strive to fulfill the number of religious education teachers, and develop their insights and capacities, especially related to teaching planning, religious social insight and creativity and innovation in developing material religious subjects.

\section{References}

[1] F. J. Potgieter, J. L. Van der Walt, and C. C. Wolhuter, "Towards understanding (religious) (in)tolerance in education," HTS Teol. Stud. / Theol. Stud., 2014.

[2] D. Gebert, S. Boerner, and D. Chatterjee, "Do religious differences matter? An analysis in India," Team Perform. Manag., 2011.

[3] F. Willems, E. Denessen, C. Hermans, and P. Vermeer, "Citizenship education in religious schools: An analysis of tolerance in Catholic schools from a virtue ethical point of view," Journal of Beliefs and Values. 2010.

[4] D. Cush, "Should religious studies be part of the compulsory state school curriculum?," Br. J. Relig. Educ., 2007.

[5] D. R. Dupper, S. Forrest-Bank, and A. Lowry-Carusillo, "Experiences of religious minorities in public school settings: Findings from focus groups involving Muslim, Jewish, Catholic, and Unitarian Universalist youths," Child. Sch., 2015.

[6] L. Revell, "Religious education, conflict and diversity: An exploration of young children's perceptions of Islam," Educ. Stud., 2010.

[7] L. Parker, "Religious education for peaceful coexistence in Indonesia?," South East Asia Res., 2014.

[8] B. K. C. Laksana and B. E. Wood, "Navigating religious diversity: exploring young people's 
lived religious citizenship in Indonesia," J. Youth Stud., 2018.

[9] W. Coleman, Elizabeth Burns, Kevin, Religious Tolerance, Education and the Curriculum. 2011.

[10] M. GENÇ, "Values Education or Religious Education? An Alternative View of Religious Education in the Secular Age, the Case of Turkey," Educ. Sci., 2018.

[11] I. Sukardi, "Character Education Based on Religious Values: an Islamic Perspective," Ta'dib, 2016.

[12] G. Corneo, "A Theory of Tolerance. Department of Economics," 2009.

[13] B. Niclas and E. Mikael, "Is Tolerance Good or Bad for Growth."; IFN Working Paper, Sweden, p. 3, 2010.

[14] UNESCO, Defining Tolerance. France: UNESCO, 1997.

[15] A. Kearns and J. Bannister, "Conceptualising tolerance: paradoxes of tolerance and intolerance in contemporary Britain., number. 2, p. 136.," Ital. J. Sociol. Educ., vol. 2, no. 2, p. 136, 2009.

[16] R. K. Pradhan, "Character, personality and professionalism.," Soc. Sci. Int., vol. 25, no. 2, 2009.

[17] T. R. Cohen and L. Morse, "Moral character: What it is and what it does," Res. Organ. Behav., vol. 34, pp. 43-61, 2014.

[18] M. Bialik, M. Bogan, C. Fadel, and M. Horvathova, "Character education for the 21 st century: What should students learn," Cent. Curric. redesign. Bost. Massachusetts, pp. 23-180, 2015.

[19] D. Court, "Religious experience as an aim of religious education," Br. J. Relig. Educ., 2013.

[20] Raihani, "Creating a culture of religious tolerance in an Indonesian school," South East Asia Res., 2014.

[21] A. Sammons, P., Lindorff, A. M., Ortega, L., \& Kington, "Inspiring teaching: learning from exemplary practitioners.," J. Prof. Cap. Community, vol. 1, no. 2, pp. 124-144, 2016.

[22] O. Serrat, "Building a learning organization," in Knowledge solutions, Springer, 2017, pp. 5767.

[23] D. Saripudin and K. Komalasari, "Living Values Education in School Habituation Program and Its Eff ect on Student Character Development,” New Educ. Revew, vol. 39, no. 1, 2015. 